\title{
Poverty Alleviation in Bosnia And Herzegovina: An Islamic Approach
}

\author{
Dr. Amra Nuhanović \\ Associate Professor \\ Faculty of Economics \\ University of Tuzla \\ Dr. Amra Babajić \\ Assistant Professor \\ Faculty of Economics \\ University of Tuzla
}

\begin{abstract}
Poverty alleviation is a problem that faces every country in the world, especially underdeveloped and developing countries. In particular, more than half population is under the risk of poverty and social exclusion in Bosnia and Herzegovina ( $B \& H$ in further text). Furthermore, unemployed people, youth, women and old people are particularly jeopardized. There are a lot of reasons for this situation: high level of unemployment, low level of education, underdeveloped and inefficient health system, aggression on Bosnia and Herzegovina between 1992 and 1995, high level of corruption, slow reforms implementation (economic, legal and political), etc. Therefore this paper is going to give an overview of the state of poverty in $B \& H$, even so it suggests the way it can be alleviated or reduced, leading to principles of Islamic economy and finance. Moreover, descriptive method of research will be used. Authors concluded that if Islamic approaches would be implemented holistically, it would be possible to alleviate poverty to a satisfactory level. The results of research can help government decision makers in formulating poverty alleviation strategies and politics.
\end{abstract}

Keywords: poverty alleviation; Islamic Approach, Bosnia and Herzegovina.

JEL Classification: I32, I38.

\section{Introduction}

Researching poverty phenomenon is in the center of interest of traditional economic theorists today. As well, it is huge challenge for Islamic theorists because of the fact they believe that Islam is unique religion which can solve all human problems. Their commitment is based on trying to formulate consistent development concept in the fight against poverty, grounded on Qur'ans principles. Poverty ratio was $18.56 \%$ in 2007, according to Household Consumption Survey in B\&H. Nevertheless, Survey shows that $22.9 \%$ of population is threatened or in risk of poverty, which with $18.56 \%$ amount $41.5 \%$ population which are poor or very close to be poor in 2007 [DirekcijazaekonomskoplaniranjeBiH, 2012] Statistical Agency of Bosnia and Herzegovina publishes Household Consumption Survey every three year, which is based on household sample, and refers to expenditures for final consumption. This Survey was supposed to be repeated in 2010, but for technical reasons it was not done. It was conducted in 2011 again. In relative poverty was $17.9 \%$ of population in B\&H in 2011. Every sixth household was poor in this country. [Agency for Statistics of Bosnia and Herzegovina, 2012] Socially the most vulnerable categories of population are families with two or more children, unemployed people, pensioners, war veterans, refuges and Roms. UNICEF Report from 2013 identified and documented serious and growing level of poverty and social exclusion in $\mathrm{B} \& \mathrm{H}$. It showed that more than half a million people live in relative poverty, and that it is possible it amounts even one million and half in $\mathrm{B} \& \mathrm{H}$. Over one million other residents live in conditions of difficult material deprivation or in situation of social exclusion which is defined like life in families with very low labor intensity[UNICEF, 2013].Bosnia and Herzegovina was in very high risk of poverty and social exclusion (AROPE-at risk of poverty and social exclusion) which amounts $58.6 \%$ of population, and is far away from average AROPE EU-27 which amounts $24.2 \%$, and far away from new EU members which AROPE amounts $30.6 \%$. Reducing poverty and economic inequalities is one of primary goals of Islamic economy. Thus, the main objective of this research is considering Islamic tools in poverty alleviation in $\mathrm{B} \& \mathrm{H}$. Additionally, authors tried to address the measures taken to alleviate the poverty by the local government. Given the previously defined subject of the research, the study aims to identify the approaches of poverty alleviation advocated by Islam. Through literature review and previous research, this paper focused on defining poverty, causes of poverty, and methods and strategies advocated by Islam. 
The study also tried to justify the importance and benefits of alleviating poverty, and why Islamic approaches are superior over conventional ones. Hence, general research hypothesis of this paper is: If Islamic approaches, would be implemented holistically - then it would be possible to alleviate poverty to a satisfactory level in B\&H.

\section{Theoretical background and previous research}

\subsection{The concept of poverty}

Poverty can be defined as not having enough money or property to buy a minimum basket of goods and services. Beside low income per capita, measured by purchasing power parity, poor world is characterized with inadequate nutritional status, bad health conditions (high degree of spread of infectious diseases), high mortality rate, especially young people, bad living conditions, a low level of education, weak or no involvement in political and social programs, frequent social unrest and wars, life in ecologically polluted areas, etc. Follows that life under conditions of poverty causes a whole series of problems to the poor on one side, but on the other side it causes potential dangers to all people and countries it the world interms of new threats to peace, contributes to the development of the network of crime and terrorism and increases the general insecurity. According to Zaks V. poverty is manifested through its four dimensions: spiritual and material circumstances; experience of your own state; how others see the poor; and socio-cultural time - a space that affects the different perceptions of poverty [Zaks V., pp. 236.]

Thus, concept of poverty refers to the lack of minimum level of material welfare in relation to consumption expenditure level, which is called threshold or poverty line. Such levels of consumption can be defined in different ways, mostly in relative or absolute terms. Relative poverty is defined as consumption expenditure level that is lower than a certain line, depending on the consumption expenditures of the whole population. Absolute poverty can be defined as consumption expenditure level that is lower than a certain line, depending on the price of y certain consumption package (UNDP). Simpler, absolute poverty refers to percentage of population living below a certain line of disposable income. Absolute line of poverty presents a minimum of the standard of living and is based on defined consumer basket. Relative line of poverty defines poverty according to the national standard of living and is determined as percentage of the average income of the population. It presents poverty through comparing different categories of population.

Nevertheless, it is possible to note that the World Bank (2008) gave most favored classification of poverty, according to which poverty is divided into:

- Extremely poverty refers to part of population who lives with less than 1.25 USD a day, measured by the calculation value of purchasing power, and

- Relative poverty refers to part of population disposes between 1 and 2 USD a day.

In assessment and calculation of poverty instead of two lines: extremely and relative poverty, there is unique „global“ line of poverty of 1.9 USD a day From October 2015. According to World Bank analysts' poverty in underdeveloped countries is calculated referring to consumption, but in developed countries, such as OECD countries, poverty is calculated referring to income [The World Bank, 2018].

If the absolute line is used to measure poverty, poverty will disappear during economic growth, meanwhile poverty measured by the relative line can only be reduced if income inequality is lower, respectively, poverty will not decrease as long as there is income inequality among social groups. Most countries in the world use relative poverty lines, mainly due to the lack of national or official poverty lines. EU countries use official lines, defined as $60 \%$ of median national income, and thanks to official lines, poverty indicators can be followed by a unique methodology [Šućur Z., 2011].

\subsection{The concept of poverty from Islamic perspective}

Poverty is one of the oldest problems encountered by human civilization. However, these problems are interpreted in the scientific literature differently. The atheists tie them to nature, some believers claim that it is God's cadre (predestination), however, a large number of those who claim that the causes of these problems lie in the unjust distribution of the wealth that Allah has bestowed upon to all the people of His goodness. What is common to all Islamic theorists on the issue of poverty is that - they have a very negative perception of the perception of poverty and that this phenomenon is generally badly reflects how on individuals and society, so on the whole people - as a dangerous social problem, the most terrible social disease and the main enemy of economic development, the greatest evilas a threat to the stability of society, the disruption of human dignity and the stability of the nation, and as a social and political problem. On the other hand, they all signal the negative consequences of poverty, in the sense that poverty deteriorates the dignity of Muslims, and that appears together with unemployment, catastrophes, (economic, political and financial) crises, borrowing, inefficient distribution of income, etc. 
Islam rejects the restriction to individual charity and voluntary charity in poverty alleviation and starts from the thesis that the solution to the exit from poverty is not to leave the poor to the wealth of the rich and what they share from pity. This gift from pity is an abstract obligation, it is not regular, nor equal amounts. If it were a regular obligation in certain amounts, then the state could picked up and distributed to the poor, and then would be one of the measures to poverty alleviation. It should be noted that, although Islam calls for modesty, moderation and the ability of man to be satisfied with what he has, the Quran do not praises the poverty, and it is considered as a problem and an accident for which the help of Allah must be sought [Kardavi J., 2003, pp. 16.]

Islam rejects the fatalistic understanding of poverty, and starts from the need to save man from poverty and to ensure equal rights for all individuals. Fatalists believe that the rich are not obliged to help the poor, and that Allah will give the supply to whom He wants Islam denies these postulates and proceeds from the fact that if poverty is the provision of Allah, then it is also the struggle against poverty and the liberation from the same - provision of Allah. Allah supplies to humanity one through another. Islam calls for satisfaction with God's determination, but not on the satisfaction of the poor in a miserable life, and the giving up of the desire to achieve a comfortable life. Also, Islam calls for not exaggerating in the accumulation of wealth, and resistance to human qualities of greed and greed.

According to Kazi Deen M., 2015, causes of poverty are: corruption, injustice, lack of ethics and morality in day-to-day activities, as well as the lack of supervision in implementing programs of poverty alleviation. His suggestions are reflected in: the modification of the education system, the introduction of more morals and business ethics into all spheres of life, the restructuring of the labour force policy, credit facilities, the retention of Zakat's obligations, and the reduction of consumption.

The UN Report Islamic Research and Information Artistic \& Cultural Institute (IRIACI) points out that the problem of poverty has become one of the greatest social problems of today, and that it can also enhance other issues, such as unemployment, crime and depression. Therefore, the Report gives priority to the postulates of Islam, which as a system of ethics and justice, deals with the alleviationand prevention of poverty. Accordingly, 3 sets of measures for poverty alleviationare listed: (1) positive - fair distribution of income (2) preventive - prevention of abuse in the fair distribution of wealth and (3) corrective measures. The same classification of mentioned sets of measures for poverty alleviationcan be also found in the Islamic theoreticians Sadeq A., 1997.

Korayem \& Mashhour 2014, compile a comparative analysis in the interpretation of the concept of poverty, in explaining the key distinctions between conventional and Islamic economics. Namely, they come to the realization that in the conventional economy there is a distinct division of: the poor and the so-called ultra-poor, while on the other hand, in the Islamic economy, there are two other groups, besides these mentioned two classifications: the first, socalled Algharimun, the poor who are overburdened with debts or who are lost their possessions due to a natural disaster, and another so-called Ibn al-Sabil (traveller) that denotes any person who does not have enough resources to realize his needs when travelling or absent from home.

Reducing poverty to a sustainable level, in Islamic frameworks, deals also, Akhtar M., 2000. As with previous authors, his approach to the interpretation of poverty is based on the Qur'an. According to the given interpretation, poverty is defined as a lack of basic material, social and political elements, which are necessary for welfare. Therefore, the author claims that the causes of poverty in Islamic countries include: the lack of functioning of socio-economic and political institutions, and the inadequacy of the moral system of values. Accordingly, Akhtar proposes a strategy of 10 elements, and in the first place emphasizes education and technology. Also, his criticism of the current social system of economies based on interest rate is indisputable, which additionally deepens the problem of poverty. Sirageldin I., 2000, Peerzade S.A., 2012,Salleh M., 2017, etc. have a similar view on this topic.

\section{Causes and Widespread of Poverty in Bosnia and Herzegovina}

Previously presented researches indicate that poverty causes in typical Muslim countries (such as Saudi Arabia, Pakistan, Iran, Sudan, Malaysia, Rwanda, Nepal, Bangladesh, Ghana, Tanzania, Cambodia, Bolivia, etc.) are found in the following reasons. Namely, some developed countries, especially countries who were colonialists have reached the existing level of economic development for a number of reasons, including the exploitation of the human and economic resources of the countries over which they have established their power.

The free workforce and potentials of the countries they have held under their occupation are the main reason for their development. Islamic countries are rich in oil, and that also can be huge problem. Oil is a strategic raw material that is extremely expensive. However, it buys from the Islamic countries at minimal prices and after processing it is selling to them again at the far higher prices. This is one form of irregular policy which developed countries lead towards weaker economies. Uncontrolled consumption is important cause of poverty too. 
Other, but not less important, causes of poverty are: insufficient access to employment opportunities, limited access to assets such as land and capital, ignoring rural areas to favor urban areas, inadequate access to market, interest, restricted access to education, health, sanitation and water services, continuous demolition of natural resources endowments and abstaining of the poor in the design of development programs that are thought to be beneficial to them. [KaziDeen Mohammad, 2015].

In Bosnia and Herzegovina, a lot of variety factors led to widespread poverty: corruption, injustice, lack of monitoring and follow up in implementing the poverty alleviation programs, war destruction, slow implementation (economic, legal and political) reforms, unemployment, human rights violations, inadequate social protection system, quality of education, and the inability to influence on the institutions of the system, etc.

Authors took the stand that solution for poverty problem should find in its causes, in Bosnia and Herzegovina. There is detailed systematization of main poverty causes in this county:

- High unemployment rate and low education rate. The main problems on labor market are reflected in the lowest employment rate of young people, women and old people, and in long-term unemployment. In addition, the education system does not monitor labor market demand. Big problem is demographic status of the country. Namely, there is a decrease in the total population in all age groups, except in the 50-64 age group, where growth is registered. Expressed unemployment rates, labor market problems, increasing number of pensioners represent a huge burden on the state.

- Aggression on Bosnia and Herzegovina between 1992 and 1995. As a result of aggression the country has suffered significant human and material losses:

250,000 killed, 200,000-400,000 wounded, social security is at risk, at the end of the war, unemployment and poverty were widespread. [Svjetskabanka, 2008]. The value of war damages ranges from 20 to40 billion USD, of which only damage to production capacities and means of work is estimated between 10 - 15 billion USD[World Bank, 1995.].High level of corruption. According to Corruption Perceptions Index 2007, Bosnia and Herzegovinatook the ninety first positionof 180 countries total and is one of the European countries with the most widespread corruption. [Transparency International, 2018.] We cannot expect decrease in poverty rates untillevel of corruption is not decreased.The inductionof a unique tax rate of $17 \%$ in has contributed to the fall in purchasing power of the population.

- Unstable political situation.

- Deep ethnic divides translate to political divides.

- Underdeveloped and inefficient health system.

- Gender inequality, etc.

The Bosnian-Herzegovinian society went through four simultaneous processes. Namely, the first was the recovery from aggression that significantly devastated human and capital resources (destroyed infrastructure, economic capacity, etc.).The financial system was built on the foundation of the old, which is time and market lost. The second process was to move from social to state ownership, and later to private property of "survived" business entities. Such a move was significantly slow, inefficient and painful, so most of the population was not ready to face the new circumstances. Adapting to new market circumstances was the third process and most reflected in attempts to establish new economic integration processes and adaptation to the globalization process. The last process involved the integration of the Bosnian-Herzegovinian society itself, represented by the image of an economically unsustainable political organization and a huge state apparatus that is still ineffective and whose public administration is incapable of responding adequately to contemporary global challenges.

\section{Research methodology}

In this paper, authors used the descriptive method of analysis. Besides that, historical method is used. Methods of analysis and synthesis, comparative methods, induction and deduction methods, classification methods, and generalization and concretization methods are applied in concluding remarks. It should be emphasized that empirical research was realized on the basis of secondary data sources, using the method of internal research (desk research). The study reviewed related literature and studies regarding to Islamic Economy and Finance, Macroeconomics and Economic Development.

The research results are presented as follows.

\section{Analysis and discussion}

\subsection{Implementation poverty alleviation tools and their results}

Assistance programs for the poor, at the international level, are conceived within the framework of the World Bank, in particular within its affiliate-IDA. 
The primary function of this affiliation is to help the poorest countries in the world, by providing them financial support in the form of loans or grants through programs that will contribute to economic development, poverty alleviation and improvement of living standards. IDA is one of the largest sources of assistance for the world's 78 poorest countries, of which 39 refers to African countries [www.worldbank.org/ida]. Together, these countries comprise a population of 2.5 billion people, of which 1.5 billion live with $\$ 2$ a day or less. The following borrowers received the funds of this association: Vietnam, India, Bangladesh, Ethiopia, Nigeria, Tanzania, and many others.

The World Bank, in cooperation with the International Monetary Fund (IMF), drafts a poverty reduction strategy (Poverty Reduction Strategy Paper) for each member country, which is a necessary document for applying for HIPC loans. Each PRSP contains the economic profile of the country, and provides guidelines for economic development with a primary focus on poverty alleviation. He represents the starting point for the drafting of national development documents and strategies.

Poverty Reduction Strategy of B\&H is also a medium-term development strategy (PRSP B\&H). The strategy proposes the realization of the following three goals: 1) Creation of conditions for sustainable and balanced economic development, 2) Poverty alleviation, 3) EU integration. [International Monetary Fund, Bosnia and Herzegovina: Poverty Reduction Strategy Paper-Mid-Term Development Strategy, Washington DC, 2004, pp. 10-32.]. Key causes of poverty towards analysts from the IMF in $\mathrm{B} \& \mathrm{H}$ are: war and slow implementation of institutional reforms, unemployment, human rights violations, inadequate social protection, quality of education, corruption, and the inability to influence system institutions. In this regard, the IMF proposed the following priority activities for poverty alleviation: [IMF, 2004]

- Ensuring GDP growth and balanced economic development of the entire country,

- Fiscal reform - efficient collection of public revenues and greater assistance to the poor,

- Accelerate the growth of the private sector in order to increase employment and a greater inflow into pension funds, as one of the most effective ways of reducing poverty,

- Establish an adequate social protection system, that will ensure minimum social rights and more even distribution of social assistance for all poor categories in the country,

- Reduce corruption, which affects the poor people at most,

- Reduce the level of grey economy, which will in the largest part lead to an increase in pensions and poverty reduction among older populations,

- Ensure the protection of human rights, which is guaranteed by the existing legal framework and signed international agreements,

- Ensure implementation of the decision on the constitution of the people, which will ensure larger integration of the returnee and Rom population into society and lead to poverty reduction among them,

- Consistently implement B\&H Law on Gender Equality, which will diminish the impact of this factor on the level of poverty,

- Reforming the education system, ensuring extra-curricular forms of education and making them available to people with low educational attainment, which is the most common cause of their poverty, and

- Establish regular consultations of government institutions at all levels with civil society, and ensure larger participation of non-governmental organizations in the implementation of social protection programs.

It can be noted that there has been a corresponding reduction in poverty in 2007, compared to 2004, which will be supported by a later analysis of poverty in B\&H. However, there is no PRSP of a recent date, and it is necessary, because many of the priorities set by the existing PRSP have not been achieved, such as for e.g. reduction of state administration costs, corruption, unemployment, improvement of statistical bases, etc.

The World Bank's more intense research on poverty was in the period 2007-2011 [World Bank, 2015]. Unfortunately, the guidelines derived from such research have not made any significant progress on the issue of alleviating poverty in $\mathrm{B} \& \mathrm{H}$.

In the context of poverty alleviation, it is necessary that $\mathrm{B} \& \mathrm{H}$ has developed adequate social programs and that the public be informed about them in a timely, through various media. However, the structure of this allocation shows that about three-quarters of this amount is paid to combat categories and their families, more than $1 \%$ of GDP is allocated to social assistance for the poor and socially excluded. In order to reduce poverty in B\&H, higher funds than $1 \%$ of GDP are needed.

\subsection{Policy measures taken by Islamic perspective}

In the Islamic economy, the first and most important place is to eradicate poverty. Generally speaking, the previous poverty reduction strategies presented in scientific literature have passed four phases. 
The first phase (1950-1960) - is concentrated on the growth of gross domestic product (GDP). Lately, Islamist economists are returning to it, where it is proposed to take into account (when calculating GDP) population growth and demographic changes. On this issue today is the UN Development Report up-to-date. Namely, this report provides that the poorest countries of the world could suppress extreme poverty within the next 20 years, if they maintain the current rates of economic growth. The UN also emphasizes trade as a key factor that has improved the situation in Afghanistan, Ethiopia, Rwanda and Sierra Leone. [UN, 2013] These progressions have never been foreseen, considering the limitations of previous poverty measurement instruments. Poverty was measured only on income, excluding other important factors such as health, education and living standards [Iqbal, 2002, pp. 10-12]. The second phase of the 1970s - attention was paid to the direct provision of nutritional, health and educational needs of the poor. The problem of poverty has become part of public policy. However, this was not sustainable in the long run, because it was a huge burden on government budgets[Iqbal, 2002, pp. 10-12].The third phase (1980-1990) - the focus is on an efficient labour -intensive model of development and an increase in investment in the creation of human capital. However, it was found that promoting intensive economic growth is very difficult, that the provision of basic services to the poor requires larger public spending, and ultimately, poor management of public funds and corruption has been noted [Iqbal, 2002, pp. 10-12].The fourth phase of the 2000s was based on the participation of the poor in decision-making, more efficient management of public funds and the protection of the poor from economic and natural shocks through public policies. Among other things, the provision of material resources to the poor, such as loans and infrastructure, market reforms, increased equity in income distribution, reduction of vulnerability and threats from potential economic shocks, financial crises and natural disasters were recorded [Iqbal, 2002, pp. 10-12].

It is interesting that many Islamic theorists base their views on poverty reduction strategies on two beliefs. The first conviction is based on the original Islamic interpretation, i.e., Quran. The phenomenon of poverty in the world is actually God's test. Those who are rich and who "have" must share with the poor, and the poor, if they are patient, be deeply rewarded for it [Iqbal (2002), pp. 12.13]. Another conviction is based on the institutionalization of the relationship between the market and the public sector, in the function of achieving redistributive goals. Therefore, the market, as an institution, is allowed to play its role, while Zakat, Awqaf, Takaful, Irfaq (non-profit sector) are permitted to correct irregularities in the functioning of the market. This means, the building of institutions that will act in an efficient and transparent way, and which will base their actions on the fair distribution of income and property [Ahmed, 2004, pp. 15].

Chapra M., 2008, notes that the concern about basic needs is a poor collective obligation (fardkifayah) of a Muslim society. As for the social impact of Zakat, it is necessary to continue to extend it, because it ensures redistribution of income, and the state uses it for the purpose of alleviating poverty. Zakat is also, designed to promote the social function of public spending.

Lately, Islamic economists advocate Islamic microfinance [Hurlburt K., 2012, Tamann L., 2014, Mahmood Z., 2015, Rokhma A., 2013, Dhaoui E., 2015, Aldosari N., 2016] etc. All of them, in fact, believe that micro crediting on Islamic principles would be an effective instrument for stimulating self-employment, which would indirectly affect poverty alleviation.

It is important to note that mentioned methods can be successfully realized only in Islamic society. First of all, Islam puts emphasis on work, which allows a person to achieve what is necessary for a normal life: food, drink, roof over head, clothing, equipment necessary for the profession and marriage. Islam is committed to ensuring that every member of society is able to work smoothly, and to be justly rewarded for it. In Islam, if they are healthy and capable of working, they are ashamed and humiliated, escaping from the possibility of earning for themselves and their families. Others are not obliged to help such people and share part of their property. An important method of combating poverty is the obligation of family members to look after each other, that the rich help the poor, heal the sick, etc.

In addition to above, we can say that the Zakat represents a great potential for poverty alleviation. According to Islamic interpretation, Zakat is the first organized law in social insurance in the world. Although the first steps were made within the framework of the Atlantic Treaty in 1941, Islam had established social security in the form of Zakat for centuries. Zakat takes: the fifth or tenth of agricultural products, other valuable property that generates income and represents the capital of the rich, or $2.5 \%$ of the money or goods of Muslims who owns a certain quantity of property in the Sharia.

Apart from Zakat, the state treasury plays a major role in poverty alleviation, which addresses the needs of the poor, when Zakat is not sufficient and represents so-called "last resort". The state treasury represents the assets of all members of a state. Muslims and non-Muslims have the right to use that property. If funds from the Treasury are not enough to undermine the needs of the poor, the state imposes rich additional obligations to fill the state treasury. 
Hence, the state apparatus in the Islamic state has an active function and, in addition to the basic duties, regularly performs the role of redistribution of income [Iqbal Z., MirakhorA., 2009, pp. 46.]

\section{Concluding remarks and recommendations}

Although there is a consensus in B\&H to address the problem of poverty, the results of the research have shown that no more serious program has been launched so far, which would be aimed at improving the economic and social position of the poor and socially vulnerable citizens.

The need for a different role of the state in the development of society, the elimination of discrimination in existing public policies, the achievement of minimum rights for all citizens, the creation of a chances of getting out of poverty, equalizing access to public services, increasing the economic safety of employees, developing social programs would significantly contribute to the implementation of poverty alleviation in $\mathrm{B} \& \mathrm{H}$, but at the same time changing the role of the state in the development of economic and social well-being. This means that, in the future, it is necessary to work on the development of an economic policy that would encourage the development and mutual cooperation between the state, the private sector and the citizens in eliminating poverty and inequality.

The authors are of the opinion that- it is the responsibility of all to alleviate the poverty, not just the government of $\mathrm{B} \& \mathrm{H}$. If Islamic approaches would be implemented holistically in $\mathrm{B} \& \mathrm{H}$, then it would be possible to alleviate poverty to a satisfactory level.

Given that B\&His a country with a predominantly larger proportion of the Muslim population and that it knows Islamic laws and regulations, the authors estimate that the strategies and measures for reducing poverty, in accordance with Islamic principles, would have a significant effect on the Bosnian society. In this regard, great potential for poverty alleviation would have: Zakat, equal distribution of wealth on the rich-poor relationship, prevention of throwing existential products and food items, etc. In fact, this needs to be reduced to a single institutional level, by adopting an organized law in the field of social insurance.

Furthermore, in order to eliminate poverty in our country, it is necessary to initially eradicate or to cause its causes to the appropriate extent, which is a very complex long-lasting process. First of all, the country needs adequate funding, either by increasing the GNP or by the inflow of foreign direct investment, it is necessary to increase employment, improve the health and education sector, and eliminate or minimize the level of corruption in the public sector.

Political causes of poverty go back to the state structure of the country, and if efforts are made in this field, then this would entail changing the Constitution. It is difficult to identify all causes, then eliminate them through appropriate strategies and policies, but it is not impossible and unachievable, and involves a long-lasting demanding process.

Ultimately, the undeniable fact is that the world is dominated by global financial institutions that create the world economic scene. For this reason, it is necessary to work on the formation of a large union into which all countries (not only developed) will enter and establish a common market. In order to do this, it is necessary to place the human factor at the center of events - the realization of common interests and the well-being of the whole civilization. This implies, again, the implementation of Islamic principles and laws who edit the rights of individuals to education, treatment, personal income, and other rights guaranteed in Islam.

Research obstaclesin this paper are:

- Lack of chronologically, internationally comparable indicators of poverty in $\mathrm{B} \& \mathrm{H}$;

- The transition of the economy in B\&His still very difficult today, because there is no adequate economic structure that would be triggered by such measures;

- The existing ruling political set and economic policy have not yet recognized the role and significance of the Islamic economy in the function of preventing key socio-economic problems and the poverty problem inB\&H.

\section{References}

Ahmed, H. (2004). Role of zakah and awqaf in poverty alleviation. Jeddah, Saudi Arabia: Islamic Research and Training Institute, Islamic Development Bank.

Ahmad, K. (2004). Studies in Islamic economics, The Islamic Foundation, Leicester, UK.

Chapra, M. U. (2008). The Islamic vision of development in the light of the maqasid al-shari ah. Jeddah, Saudi Arabia: Islamic Research and Training Institute, Islamic Development Bank

Iqbal, M. (2002.). Islamic economic institutions and the elimination of poverty.The Islamic Foundation, Leicester, UK. The United Nations (2008). The UN Millennium Development Goals. Available at :http://www.un.org/millenniumgoals/ 
Kardavi, J.(2003).Islam i siromaštvo, Bemust, Sarajevo.

Muhammad Syukri Salleh (2017).Contemporary Vision of Poverty and Islamic Strategy for Poverty Alleviation,SAGE open, available at:

http://journals.sagepub.com/doi/pdf/10.1177/2158244017697153

Kazi Deen Mohammad (2015). Alleviation of Poverty in Bangladesh: An Islamic Approach,Global Journal of Human Social Science: Arts \& Humanities - Psychology, Volume 15 Issue 10.

UN,(2017).Islamic Research and Information Artistic \& Cultural Institute (IRIACI),NGO in Special Consultative Status with ECOSOC of the United Nations,

AbulHasan M. Sadeq(1997). Poverty alleviation: an islamic perspective, MCB UP, Ltd.

Sayed Afzal Peerzade (1997). Integrated Islamic Approach to Poverty

http://www.pide.org.pk/pdf/PDR/1997/Volume1/87-97.pdf

Karima Korayem\&Neamat Mashhour (2014). Poverty in Secular and Islamic Economics Conceptualization and Poverty Alleviation Policy, with Reference to Egypt, Topics in Middle Eastern and African Economies, Vol. 16, No.1

Muhammad Ramzan Akhtar(2000). Poverty Alleviation on a Sustainable Basis in the Islamic Framework, Pakistan Development Review39 : 4 Part II pp. 631-647

Ismail Sirageldin (2000).Elimination of poverty: challenges and islamic strategies, Islamic Economic Studies, Vol. 8, No.1.

Svjetskabanka (2015). Siromaštvo i nejednakost u Bosni i Hercegovini 2007-2011, Svjetska banka, Washington D.C. Kajia Hurlburt (2012).What is Islamic Microfinance?Shuraako. orghttps://shuraako.org/sites/default/files/What\%20is\%20Islamic\%20Microfinance.pdf

Luqyan Tamann (2017).Introduction to Islamic Microfinance,Centre for responsible Banking and Finance, WP No 17-013

Zahid Mahmood (2015). Islamic Microfinance and Poverty Alleviation: An Empirical Assessment from Pakistan,Journal of Islamic Economics, Banking and Finance, Vol. 11 No. 2.

Aahibur Rokhma (2013). The effect of islamic microfinance on poverty alleviation: study in Indonesia, Economic Review: Journal of Economics and Business, 2013, vol. 11, issue 2, 21-30

Elwardi Dhaoui (2015).The role of Islamic Microfinance inPoverty Alleviation: Lessons fromBangladesh Experience,MPRA Paper No. 63665, available at https://mpra.ub.uni-muenchen.de/63665

BaderNasserAldosari, (2016). Islamic Microfinance System And Poverty Alleviation, International Journal of Development and Economic Sustainability, Vol.4, No.6, pp.33-44

Iqbal Z., MirakhorA., (2009). Uvod u islamske financije: teorija i praksa, Mate, Zagreb

DirekcijazaekonomskoplaniranjeBiH (2012).IzvještajorazvojuBiH 2010/2011, IIdio, Sarajevo.

AgencijazastatistikuBiH (2012).Anketa o potrošnjidomaćinstava u Bosni I Hercegovini, 2011., Sarajevo.

UNICEF (2013).Analizanedostataka u oblastipolitikasocijalnezaštite I inkluzije u BiH, Sarajevo.

ZaksV. (2001).Rečnik razvoja: Vodič kroz znanje kao moć, Svetovi, Novi Sad.

The World Bank(2008). World Bank Institute- Learning for Development, Washington D.C.

Iqbal, M. (2002.). Islamic economic institutions and the elimination of poverty.The Islamic Foundation, Leicester, UK.

Kardavi, J.(2003).Islam isiromaštvo, Bemust, Sarajevo.

The World Bank, www.worldbank.org, accessed: November 2018.

Transparency International, www.transparency.org, accessed: November 2018.

World Bank (1995). Bosnia and Herzegovina, Priorities for Recovery and Growth, Washington D.C.

Svjetskabanka (2008)Poboljšavanježivotaljudi u Bosni I Hercegovini, UredSvjetskebanke u Bosni I Hercegovini. 